\title{
"The community school literally takes place in the community": Alternative Education in the Back-to-the-Land Movement of the West Kootenays, 1959 to 1980
}

\author{
Nancy Janovicek \\ University of Calgary
}

\section{ABSTRACT}

This article examines two alternative schools developed by back-to-the-land communities in the West Kootenays, British Columbia. The Argenta Friends School offered an alternative education in a rural community to senior high school students. Quaker observation informed the school's consensus governance and self-directed learning. The Vallican Whole School was a product of the Slocan Valley counterculture, and taught children from age six to sixteen. Children were encouraged to pursue their own interests rather than to follow a strict curriculum. Although they had different approaches to education, both schools emphasized the importance of learning rural skills as the foundation of an education that encouraged students to thrive in the place where they lived.

\section{RÉSUMÉ}

Cet article traite de deux écoles alternatives fondées par deux communautés prônant un retour à la terre dans les West Kootenays en Colombie-Britannique. L'Argenta Friends School offrait une formation alternative en milieu rural à des élèves de niveau secondaire avancé. La gouvernance par consensus et l'apprentissage autodirigé de l'école s'appuyaient sur l'idéologie des Quakers. La Vallican Whole School influencée par la contre-culture de la vallée de Slocan, enseignait aux élèves de six à seize ans. Les enfants étaient encouragés à poursuivre leurs propres apprentissages au lieu de suivre un programme d'études bien défini. Malgré leurs approches différentes, ces deux écoles mettaient l'accent sur l'acquisition des compétences qui aideraient les élèves à prospérer dans le milieu rural où ils vivaient.

\section{Introduction}

How to educate children to become engaged citizens, and what skills they required to become productive adults has been a continual theme in debates about education. After WWII, when children became rights-bearing individuals, it was more 
common for policy-makers, pedagogical theorists, and child psychologists to recommend democratic approaches to child-rearing and teaching. ${ }^{1}$ These ideas, however, were not generally implemented in homes and schools. ${ }^{2}$ Since the early twentieth century, progressive educators have blamed the school system, and in particular the authoritarian relationship between teacher and pupil, for stultifying democratic thinking. John Dewy's criticism of authoritarian educational practices is perhaps the most famous North American example of how the undemocratic organization of the school system limited children's freedom of thought, a crucial component of democratic participation. Montessori and Waldorf schools were early-twentieth century alternatives to rote education that emphasized individual exploration and purposeful activity as keys to childhood development. In the 1960s, these alternatives began to take hold in North America, but remained on the margins of the educational system. Although these schools were more child-centred than public schools tended to be, they still followed specific child-development theories and educational methodologies. More radical criticisms of education that insisted that children's freedom should be at the core of education emerged out of the counterculture in the 1960s. Like the counterculture itself, media depictions of these experiments with education presented a homogenous description on what was, in fact, a complex and diverse set of experiments in teaching young people how to "live otherwise."3

Drawing on newspaper articles from the mainstream and alternative press, oral histories, and the privately-held records of political groups, this article examines two alternative schools organized by back-to-the land communities in the West Kootenays of British Columbia. It is part of an on-going research project on the impact of this movement on the economic, social, and cultural development of the region. The Argenta Friends School opened in 1959, and was run by the Argenta Friends Meeting, a small group of Quaker families who had moved from California to the isolated community in 1952. The first students were the children of these families. In the mid-1960s, the school began to offer a rural-based alternative education to senior high-school students who did not live in Argenta. The school combined traditional curriculum with rural skills, and followed a cooperative governance structure based on the Quaker consensus models. Parents from the back-to-the-land community in the Slocan Valley organized a home-schooling collective called the Free School in 1972. The school moved between parents' homes until the completion of the Vallican Whole Community Centre in 1976, and was renamed the Vallican Whole School. ${ }^{4}$ These two schools provided alternatives to the public school system that were very different from each other. Religion was at the core of the Friends School and the curriculum followed the provincial curriculum with the goal of preparing the students for postsecondary education. In comparison, the Whole School eschewed established lesson plans, and provided a space for self-guided exploration. What these schools had in common was a commitment to encouraging students to become independent, critical thinkers who would be engaged in their community and the world. Learning rural skills based on traditional knowledge was another core value that the schools shared.

The organizers of the schools were part of a long tradition of rural protest against reforms that presumed that country life was backwards and concomitant demands 
for adequate resources to support locally created solutions to social problems. ${ }^{5}$ Although people had different reasons for moving to the country, the back-to-theland movement was fundamentally an attempt to create alternatives to destructive economic and political developments that they associated with overcrowded, polluted, and increasingly violent cities. Self-education, self-reliance and local control over governance and resources were central tenets of the counterculture. These were also rural values, as the agricultural education movement of the 1920s and 1930s aptly demonstrates. A significant proportion of the new homesteaders in the West Kootenays had moved from the United States and introduced new political ideas to the region. Those who moved from Canadian cities were also more likely to hold university degrees than their neighbours who had grown up in the region. Yet those who were politically engaged were attentive to the guidance of elders in the community who shared their views, and their politics were firmly grounded in the place where they lived. These schools were, to varying degrees, a rejection of rigid curriculums that were designed to meet government agendas that privileged urban technological development over rural and resource-based economies.

I begin with a discussion of the theories and debates about free schools and counter-cultural child rearing practices in the 1960s and 1970s. Many of these debates focused on urban experiments in economically, racially, and ethnically marginalized communities that drew on radical pedagogical theories from decolonization theorists. Prominent advocates for alternative education dismissed rural countercultural experiments as examples of the abandonment of the radical potential of the "free school" movement. This paralleled sociological analysis of raising children in counter-cultural communes that focused on cultural rejection of social mores and values. These studies tended to focus on communes rather than back-to-the-landers who owned their homesteads, and sociologists paid little attention to the political goals of rural countercultural communities. The two case studies presented in this article are only two examples of alternatives to public school education in the Kootenays, but are representative of the diverse experiments in alternative education in British Columbia in the 1960s and 1970s. ${ }^{6}$ The schools' focus on student-guided education, independence, and learning by doing drew on older progressive theories of education as well as the countercultural "DIY" emphasis on self-education, decentralized knowledge, and mutual aid.

\section{Radical Education in the 1960s and 1970s}

In the mid-1960s, proponents of radical education in the United States reacted to government calls for more rigorous education that emphasized science, technology, and math over the humanities, creativity, and critical thinking. Cold war anxieties that democratic nations were falling behind Communist states instigated government educational reforms. ${ }^{7}$ Critics argued that the new pressure to produce smarter and more technologically savvy children not only increased their anxieties about failing, but also ensured that they would not succeed. Increasing emphasis on raising educational standards, rather than fostering intelligent children's path to self-discovery, 
made children "bored, fearful, and confused." ${ }^{8}$ Concern about failing children from marginalized communities was another theme in the widely read books that advocated alternatives to the public education system. Written by radical educators who had witnessed how racism and class prejudice made the desegregation of schools in the United States ineffective at promoting social equality, these books explained how community-based schools provided the only viable alternative to the discrimination that racialized, poor children faced in under-resourced inner-city schools. ${ }^{9}$ Working closely with parents and community developers, advocates for inner-city free schools distinguished themselves from alternative schools with high tuitions that served privileged children. These apolitical schools would not bring about social change because they ignored racial and class exploitation. Jonathan Kozol, a prominent free school activist based in underprivileged communities in Boston, was especially dismissive of the political potential of educational experiments in rural communes. Stereotyping commune members as the privileged children of the middle and upper class, he chastised back-to-the-land communities for abandoning revolutionary politics:

At best, these schools are obviating pain and etherizing evil; at worst, they constitute a registered escape valve for political rebellion. Least conscionable is when the people who are laboring and living in these schools describe themselves as revolutionaries. If this is revolution, then the men who have elected Richard Nixon do not have a lot to fear. They would do well in fact to subsidize these schools...for they are an ideal drain on activism and the perfect way to sidetrack ethical men from dangerous behavior. ${ }^{10}$

Kozol's disdain for people who moved to the country to escape from urban violence and pollution and fractional left politics is representative of a broader New Left critique the back-to-the-land movement. Radical education was supposed to be about social change; these educators did not believe that this could not be achieved by retreating to the country.

In Canada, This Magazine is about Schools was the most significant publication that provided a venue for educators to interrogate the state of the public school system and to debate what pedagogies would enable children to achieve their full potential. Published between 1966 and 1973, the editorial board did not share a common vision about the connection between education and social change. ${ }^{11} \mathrm{~A}$ product of Toronto's experimental free university, Rochdale College, ${ }^{12}$ its editors presented teachers with educational materials that promoted social equality, resources for social justice subjects like working-class and women's history, and approaches to child-centred learning. A few articles discussed rural alternatives, but did not analyze in a meaningful way how rural skills could be integrated into curriculum; nor did they examine the specific challenges that people developing alternative ideas in the country faced. ${ }^{13}$

Parent involvement in schools was a central theme of the magazine. Demands for more parental involvement in schools were prevalent. In his 1975 book, About Schools: What every Canadian parent should know, Robert M. Stamp reported that 
even Chatalaine magazine, the bastion of mainstream suburban Canada, had published articles by June Callwood and Michele Landsberg that encouraged parents to be encouraged in their children's education. ${ }^{14}$ Stamp argued that parents were frustrated with changes in government education policy because they followed obscure trends in educational theory and governmental economic priorities instead of developing curriculum that would prepare children to be critical thinkers who were interested in the world. He also criticized school administrators and teachers who treated parents like trespassers and people who were ignorant of how to best teach children. Stamp believed that alternative schools were a corrective to this trend because, despite the many different models and mandates they followed, all of these schools shared a commitment to community-based education and most of them were governed by parent-teacher cooperatives.

In his study of British Columbia alternative schools, Harley Rothstien argues that parental opposition to the 1960 Royal Commission on Education, better known as the Chant Report, instigated the establishment of many alternative schools. These parents rejected the report's call for a return to traditional, academically rigorous approach to education and because it relegated "the creative arts and self-expression to frill status." ${ }^{15}$ The Chant Report was not entirely dismissive of progressive approaches to education, and recognized that these democratic methods of education were an improvement on older practices based on repetition and punishment. It did not, however, embrace the core philosophies of progressive education that promoted self-expression, independence, and cooperation. Indeed, the report recommended that competition should not be eliminated from the classroom, arguing that students who demonstrated academic excellence should be rewarded in a similar manner to athletes. It also discouraged too much emphasis on developing lesson plans to suit students' interests, arguing that teachers tended to introduce "time wasters" into their lesson plans instead of developing creative ways to engage students in hard subjects that would ultimately be more useful to students in their adult life. Discipline was important for maintaining an authoritarian relationship between teachers and pupils. The report distinguished between "central subjects", "inner subjects," and "outer subjects," classifying English, science, and math as core courses, and relegating courses such as art, physical education, and drama to the periphery of curriculum development. ${ }^{16}$ The Chant Report was the foundation for curriculum development in the public school system. School trustees and administrators embraced the report, but the emphasis on discipline, authority, and competition were out of step with the emerging ethos of the period. ${ }^{17}$

Parents who believed in a more humanistic approach to education, and who could mobilize the resources to do so, organized alternative schools based on their own values. Many of schools were not independent, private schools. They were based and developed in community but had an affiliation with the state through their integration into the public education school system. Some books about free schools were also guides to helping other communities deal with the regulatory apparatus that governed schools, and to maintain their independence within that system. ${ }^{18}$ The strong tradition of private schools in British Columbia produced a unique 
relationship between alternative schools and the public education system. It was not until 1977 that the provincial government introduced legislation to regulate independent schools, which allowed radical experiments to flourish. By 1975, some of the independent alternative schools chose to integrate into the public school system. ${ }^{19}$ For parents in isolated rural communities who wanted to establish independent schools, finding adequate resources to operate community-based school was difficult. Ten students was the minimum enrolment to qualify for government funding. The school in Johnson's Landing, near Argenta, had survived for two years on volunteer support, but the parents were running out of energy. They sought support from other parents to coordinate a lobby to raise issues about educational funding for isolated rural communities. ${ }^{20}$

Although Rothstein recognizes the influence of the Social Gospel and socialist traditions on progressive education, he argues that the American academics recruited by the University of British Columbia in the 1960s and 1970s introduced radical pedagogical ideas to the province. Free schools that emphasized the freedom and independence of the child are most often associated with the counter-culture. The nascent historiography on Canadian counter cultural communes tends to emphasize the influence of Americans who emigrated from the United States. Attributing ideas to a national identity does not recognize the dynamic interplay between global and local ideas. This article follows the insights of transnational history to make sense of how ideas developed as they moved with people through places and seeks to understand how an international dialogue about education played in two local rural contexts. ${ }^{21}$ The West Kootenays attracted many Americans who rejected the politics and policies of their country of origin. But analyzing the political and cultural impact of the back-to-theland movement on the region primarily as an American phenomenon puts exclusive importance on the place of origin of some of the people in these rural communities in the region, and does not consider how their politics were rooted in place. In the next section, I provide a brief background of the migration of urban people to the area; many who moved to the area placed themselves into a longer tradition of migrations people seeking alternatives to the status quo. They turned to these older communities to seek out traditional skills and the knowledge that they would need to survive in the country. These rural skills were then integrated into the schools that the Quakers and the countercultural parents organized in Argenta and in the Slocan Valley.

\section{The Back-to-the-Land Movement in the West Kootenays}

In the 1960s and 1970s, hundreds of people moved to the West Kootenays to live a self-sustaining life closer to nature. The back-to-the-land movement was a diverse community including transient hippies, communards, draft resisters, New Left activists, artists, and young families. It is unclear how many people moved to the region, but between 1966 and 1971, the beginning of the new migration to the region, the population of the Slocan Valley increased by $420 .{ }^{22}$ In the bucolic settings that were the hubs of the back-to-the-land movement, the arrival of young families looking for a self-sustaining alternative to city living reversed years of rural depopulation in the 
region. As land in the United States and on the British Columbia coast became too expensive for young families, people began to move to the interior of British Columbia and other Canadian rural communities where land was cheap. ${ }^{23}$ Some of the families who moved to the region were people who had left professional positions, giving them some financial security. But, contrary to the assumption of much of the contemporary New Left criticism of rural countercultural communities, these "new homesteaders" were not uniformly the privileged children of white, affluent families. The precarious nature of agricultural economy, coupled with the lack of farming experience of many of the back-to-the-landers, meant that in the early years most people had difficulty making ends meet. Living arrangements and landholding patterns varied. The New Family was one of the first, and most successful, communes in the region because it established guidelines for collective work and prohibited drug use. ${ }^{24}$ Other experiments, like the Red and Blue Commune, were less successful. Intentional communities, such as the Argenta settlement, distinguished themselves from communes by following cooperative models of ownership. ${ }^{25}$ Others owned their land independently and some squatted on crown land.

The back-to-the land movement of the region made connections to older religionbased intentional communities that led cooperative and pacifist lifestyles. The West Kootenays was a destination point for people looking for a place to live according to values that did not accord to the liberal hegemony throughout the twentieth century. Doukhobors migrated from Saskatchewan to southeastern British Columbia between 1908 and 1922 in opposition to pressure to own homesteaded land on an individual basis. They owned land collectively, and established self-contained communities that had little contact with their neighbours in the Slocan Valley and near Castlegar. After the Second World War, debates about individual and collective land ownership divided the community. A minority of the community, the Sons of Freedom, continued to follow religious values and the tradition of collective landholding. After the war, increased civil disobedience, which was sometimes violent, to defend their lifestyle raised the ire of neighbours and the government. In the 1950s, many children from Freedomite homes were forcibly removed from their families because their parents refused to send them to school, arguing that the public school system would assimilate their children into mainstream society. ${ }^{26}$ The Whole School parents also faced threats of imprisonment when they refused to send their children to school, and the affiliation that some of them felt to the Sons of Freedom will be discussed below.

The values of the Doukhobors were inspirational to those who moved to the Slocan Valley as part of the counterculture. Many people interviewed to date for this research purchased their land from Doukhobor families and recalled that they learned how to garden, can and preserve food, build homes and barns, and other rural skills from the elder Russians whose children were leaving the valley, and who were excited to see young families returning to the region. ${ }^{27}$ Bob Ploss moved to the Slocan Valley in 1966. He and his wife were among the first back-to-the landers in the region, and he stated that there were few tensions between the new homesteaders and their neighbours when they arrived. His recollections about the support from neighbours is representative of many stories that I have heard conducting oral histories: 
We didn't make a secret of where we were and what we were doing, we had a lot of support from the local Russians, especially the Sons of Freedom branch of the Doukhobors, Peter and Ellen Demoskoff and Mary Speirka were especially kind to us, and they showed us how to garden and lent us tools and plants to get started with, and helped us out with the building project, because we were building essentially a pretty large house with no electrical power. ${ }^{28}$

Opposition to the Vietnam War also fostered positive relationships with their new neigbours. Ploss was very involved in anti-Vietnam War activism at Berkeley College in California. He avoided the draft by fasting so that he would be deemed unfit for service, but fled from the United States because of the authorities were monitoring his political work. The Kootenays became a refuge for Vietnam War draft resistors because of the connections between Vancouver anti-war activists who moved to the area, and Quaker involvement in the peace movement.

Ten Quaker families moved from California to Argenta, in the Larendeau Valley east of Kootenay Lake, between 1952 and 1954 because they believed that McCarthyism, increased cold war tensions, and opposition to the Civil Rights movement were evidence that the United States would never be a society that accorded with their pacifism and commitment to social justice. Although they deliberately settled in an isolated area, they remained engaged in politics, and it was common for members of the community to leave for extended periods to participate in community-based development programs around the world. ${ }^{29}$ Betty Tillotson, who was a teacher and housemother for the school, described the relationship between Argenta and the outside world: "It's home; it's where we've put down roots; it's the much-loved centre of our lives. We go out and contact with the world — to travel, to work, to visit, to shop, even to live somewhere else for awhile — always coming thankfully home." ${ }^{30}$ These first families established the Delta Co-op, a collectively owned farm, to provide an economic foundation for the community, and young families joined them in the late 1960 s and 1970s. Some, but not all, of these newer families were Quaker. The community was always small, and had a permanent population of about 130 .

The back-to-the-land movement is often characterized as a romantic anti-modern rejection of urban living and technological society. Back-to-the landers did reject capitalist values, but the decision to learn traditional skills was, for many, rooted in a commitment to social justice and an attempt to live according to post-scarcity economic theories. More recent studies that examine the political countercultural embrace of appropriate technology, most popularly advocated by Robert F. Shumaker in Small is Beautiful, challenge the stereotypes about counterculture. ${ }^{31}$ Appropriate technologies were cheap, small-scale machines and tools that were designed for specific purposes. To foster local control over resources, these "intermediate technologies" were also easy and cheap to make. Many turned to older methods and practices because they had these characteristics. People came to the country with few of the skills that they needed to survive in the county. Determined to be self-sufficient, and aware of their own impact on the environment, new homesteaders read farmers' almanacs, the flurry of guides for back-to-the-landers, and the Whole Earth Catalog. ${ }^{32}$ 
Passing this knowledge to children and youth was part of the experience of living on the land, and teaching young people practical rural skills was as important as academic subjects at the Friends School and the Vallican Whole School. ${ }^{33}$ Contrary to the priorities of the provincial curriculum, which emphasized knowledge that would help Canada compete in a modern urban world, the alternative schools under discussion here included older knowledge and technologies that worked in the country to teach their pupils how to be self-sufficient, but also engaged in the world beyond their community.

\section{The Argenta Friends School}

When the first Quaker families arrived in the Argenta, the school that had educated previous generations of children had been closed due to rural depopulation. Some parents sent their children to live with Doukhobor families so that they could be educated by people who shared their communal and pacifist values and to learn that practical rural skills that their parents did not know. These families chose a simpler life in an isolated community so that their children would not be influenced by materialism and militarism, and in the new environment their children took on more responsibilities than they might have had they lived in town. Because there was no electricity when they arrived, children's work was crucial to the family economy. They cut down trees, worked in the gardens and on the co-operative farm, and helped to refurbish old homestead homes. ${ }^{34}$ Getting to town was difficult because, before the road was built in the mid-1960s, the ferry was the only access to the Argenta. The children in the community needed a school that was close to home, but because there were not enough families to qualify for provincial funding, they had to organize a private school. An independent school also ensured that the families could realize their hope of raising their children in a community that was not inundated with media messages and social pressures to conform to consumer culture. ${ }^{35}$

The Argenta Friends Meeting opened a school in 1959, and offered courses for students from grades ten to twelve. The tuition of $\$ 800$, and the monthly salary for teachers was $\$ 75.00 .^{36}$ John and Helen Stevenson, who were one of the original families to move to the community, founded the school. They had been teachers in California, and left because they refused to take an oath of loyalty that the state introduced for teachers and other public servants during the McCarthy period. Classes were held in the Friends Meeting Hall, which was constructed by parents, teachers, and students in $1961 .^{37}$ The school soon became a central institution in the community. Almost everyone participated in the school, even if only for a short time. Many who were not hired as full-time teachers offered courses in their area of expertise, or taught subjects that were not part of the provincial curriculum. For example, Liz Tanner, who moved to the community in 1973, did the research to prepare a sex education class. ${ }^{38}$ Most people in the community served as house parents to the students who came from other communities in the United States and Canada looking for an alternative education in a rural setting. They received a monthly allowance from the tuition to cover food costs. Students' relationship with teachers 
was sometimes complicated if they also lived with them. The school revitalized the community before the arrival of back-to-the-landers in the 1970s. In addition to the students, people moved to Argenta to teach at the school. Students were involved in all aspects of the community. The Argenta Friends Press, which still publishes the Canadian Friend and the Canadian Quaker Pamphlet series, was founded by one of the teachers for a project that taught students how to publish. Initially, they produced school materials and in 1979 the class published The Argenta Cookbook, a fundraiser for the school. The press moved from the basement of a community member to a new building, which the students helped to build, when it expanded to take on publishing contracts. ${ }^{39}$

Quaker observation was the core value of the school. In adherence to the Quaker consensus model, students had equal voice in administration and curriculum development. Some of the students whom Rothstein interviewed believed that the adults and the Friends meeting had final authority over decisions, and were thus confused about why they were encouraged to participate in decision-making. ${ }^{40}$ There were prohibitions against drug use and drinking in the school, which may have upset students who believed that they should be free to make these decisions for themselves. Although most of the students were from Quaker families, those who were not raised in this tradition may have been confused by how Quaker consensus worked. Anni Valentine moved to Argenta with her family in 1955 and attended the Friends School in the early 1970s. The consensus model at the school was not exceptional to her because she was raised in the Quaker community and by parents who, as will be discussed below, believed that children flourished through self-guided learning. ${ }^{41}$

Rothstein argues that the organizers of the school were not motivated by educational theories. Instead, building community in a wholesome rural environment and encouraging students to observe Quaker values were the priority of the school. A commitment to Quaker values and developing a curriculum that considered the development of rural skills to be as important as the provincial curriculum is not, however, necessarily evidence of lack of attention to pedagogy. Teachers were committed to preparing students for post-secondary education. Betty Tillotson, who moved to Argenta in 1973, served as a housemother and teacher for the school, recalled that although it was meant to be an alternative to the public education system, the school provided rigorous courses:

In those early years it seemed to be doing something unique. It had a strong academic program, so they learned all of the things that they needed to or that were generally thought the things that they needed to go to college and continue in education. But they also learned how to be part of families and do things like milking cows and harvesting gardens and all of those other things. ${ }^{42}$

Moreover, they hired qualified teachers to teach English, science, and math. Advertisements for teachers specified that they would also serve as house parents, and that they should be "interested in dedicated service within the Quaker context." ${ }^{43}$ Teachers were not, however, specialized. Betty Polster moved to Argenta in the late 
1960 s, and was the principal of the school for many years. She held degrees in science and math and described herself as an "odds and ends" teacher. Because the school was so small, teachers had to be flexible. And because the school was woven into the community, teaching responsibilities included practical tasks, such as the maintenance of the school and agricultural work. ${ }^{44}$

Argenta was an intentional community, and those who moved there were committed to alternative child-rearing values. But not all of the children who grew up in the community attended the free school. Peter Schramm, who moved to the community as a child with back-to-the-land parents in the 1970s did not go to the Friends School because he wanted to distance himself from his parents' "hippie values." He chose to attend the public school instead. ${ }^{45}$ Ric Valentine, Anni's older brother, did not enroll in the school because when he was sixteen years old he decided to work instead. He had attended alternative schools in Vancouver before then, including two years at the Know School in Vancouver, which was organized by teenaged students with funding from the Company of Young Canadians. Valentine explained that this was an educational experience, but not one that gave him a solid academic background. One reason that he decided to work instead of completing high school was because he was embarrassed that his math skills were weak, and that he would stand out in the class. Although the family moved in and out of Argenta, and he attended alternative schools outside of the community, his most important education was outside of the classroom learning practical skills. When he was eleven, his father purchased twenty acres of crown land for him at a government auction and paid $\$ 25.00$ per acre. In exchange for cheap land, he had to complete $\$ 500.00$ of development on the property. He learned how to do this by himself: "My dad bought me a case of dynamite, showed me how to use it. And I made the road into here and started skidding logs with a horse and...this room we're in right now is what I started building when I was fourteen." ${ }^{46}$ Chuck Valentine, held a master's degree in education and gave his children a lot of freedom to direct their own studies. Valentine described his father's pedagogical philosophy and their unconventional education:

He really believed that the whole education system is way too structured and that if you give kids lots of opportunities, then they will do a lot of self-guided learning...[He] was not committed to us going to school everyday. If we had something better to do, that was fine by him. And mostly when I was in school, I got really good marks; it wasn't hard. So twice they took us right out of school for most of the winter and we went travelling in Mexico...my sister was studying weaving so we went to Indian villages that white people never went to, so she ended up learning different weaving techniques. ${ }^{47}$

Practical skills that were essential to a self-sufficient rural lifestyle were an essential component of an education that sought to develop the whole person. The parents and teachers believed that teaching young people to become independent and selfreliant was best achieved in a less structured setting than the public school system, which insisted on developing hierarchical authoritative relationships, could provide. 
The school closed in 1982. Those who were involved in the school list various reasons for its closure. Salaries were low, and this made it difficult to keep teachers, especially those who were not Quakers, at the school. Those who did stay were drawn to the back-to-the land lifestyle and committed to the Friends Meeting. Some parents sent their children to the school because they had been in trouble with the law and hoped that sending them away from negative urban influences would put them on the right path. This idyllic image of rural life was not accurate, and these young people could acquire drugs in the nearby towns, and also from the countercultural communities near Argenta. It was difficult for the host families to deal with the behavioural issues that these children introduced to their homes. As the population of Argenta aged, people had less energy to commit to the school. Most of the young people who were educated at the school did not return to the community to live the back-to-the-land lifestyle of their parents. In addition, fewer people attended the Friends Meeting. Quaker values that were the foundation of the school and without a revitalization of the meeting, there were fewer people to work at the school.

\section{The Vallican Whole School}

The Vallican Whole School was a free school for children, ranging from age six to sixteen of the back-to-the-land families in the Slocan Valley. In comparison to Argenta, the back-to-the-land movement in the Slocan Valley did not have religion to unite them. What they shared was a commitment to living a simpler ecologically aware life, and to becoming self-sufficient by learning essential rural skills, such as growing their own food, building their homes, and raising livestock. Like the Argenta families they believed that by moving to the country they would be able to protect their children from the increasingly antagonistic politics and violence in cities. Their philosophy of child rearing aimed to equalize relationships between parents and children, and to create a community in which children were welcome and invested. Michael Pratt, one of the founders of the Whole School, explained that countercultural parents wanted to give their children freedom. Because many of the children in the counterculture were not raised in nuclear families, child rearing tended to be more communal:

The kids were more able to grow naturally instead of being programmed by teachers and parents to mind your Ps and Qs and all those old fashioned ways of doing schooling. And bringing up kids at home and realizing that we all, the whole community was kind of like parents to all of the children. So we all looked after each other's kids, and we reorganized families, and the kids were still loved, and there wasn't that same trauma if mom and dad split up and had new partners. And somehow the Whole School gave the kids a feeling of identity and were somewhat more flexible in social situations. ${ }^{48}$

Self-designed learning mirrored a fundamental countercultural value of teaching oneself. This DIY philosophy of the back-to-the-land movement was also based in 
a commitment to the decentralization of authority and an emphasis on local control over knowledge and resources.

The Whole School began as a homeschooling cooperative of parents who had decided to pull their children out of the public schools because they did not agree with the emphasis on discipline and strict adherence to curriculum. These families also decided not to send their children to public school because students who were not part of the counterculture harassed them at school. In newspaper interviews, school organizers emphasized the children's role starting an alternative school. Tom Drake, an early coordinator of the homeschooling collective, explained why their children made the decision to drop out of the public school: "They were getting a lot of hassles from other kids at public schools because of their long hair and different appearance and the were really beginning to hate the idea of going to school." ${ }^{49}$ Parents were equally frustrated with the political bureaucracy, and argued that school boards were more concerned with financial matters than with the well being of students. ${ }^{50}$

New homesteaders began the alternative school in the midst of protests against the increased cost of education in the existing schools in the valley. In 1970, rural school districts had been amalgamated so that the under-resourced schools in the valley would be integrated into a more prosperous district. Two years later, parents signed a petition protesting against more expensive school supplies that the new district supplied to students and demanding that the board follow through on the promised improvements to the schools. ${ }^{51}$ Hopeful of new possibilities under an NDP government a delegation of homeschooling parents went to Victoria to lobby for more educational resources for the valley. The deputy minister told them that people living in the interior of the province should not expect the same resources as those living in more populated areas. ${ }^{52}$ The parents were more determined to keep the free school open, but founding an alternative school that would only appeal to a minority of the parents in the valley did not make sense to many people, especially those who believed that too many tax dollars had been wasted on funding projects initiated by the new residents. ${ }^{53}$

The school was mired in the controversies about the new lifestyles and projects that the counterculture introduced to the valley. The Vallican Whole was a lightning rod for opposition to federal grant programs that funded community-based projects organized by unemployed youth. Back-to-the-landers founded the Rural Alternatives and Training Society (RARTS) in 1971 because youth who were moving from urban areas to the country did not have the "necessary skills which would enable them to be productive and independent in a rural area." ${ }^{54}$ RARTS' aim was to develop viable job opportunities for these young people, who could not find employment in agriculture or in the logging industry in the Valley, and to do research on ecological alternatives to wasteful industrial production. Not only would they provide much needed employment and training to newcomers, but they would also tap into the expertise that the new residents brought to the valley. ${ }^{55}$ They successfully applied for a grant from the Opportunities for Youth (OFY) program to build a vocational centre that would draw on knowledgeable people in the region to teach rural skills. ${ }^{56}$ RARTS secured a site in Vallican, and when the funds from the grant were depleted, they had only poured the foundation. Those involved in the project believed that it had been 
a worthwhile project, and explained that their inexperience led to goals that were too ambitious to be achieved during one summer. ${ }^{57}$ But long-time residents complained that they had done nothing more than waste taxpayers' dollars and to create an eyesore in the community, which they dubbed the "Vallican Hole." ${ }^{58}$ A vocal group of residents complained that the newcomers "did not intend to become respectable citizens of our communities" and that they used the grant money "to further separate themselves from the social structure." The free school was another example of their rejection of the established institutions in the valley. ${ }^{59}$

Controversies about homeschooling in the "hippie homes" were also rooted in older conflicts with the Sons of Freedom. In the 1950s, Freedomite parents refused to send their children to school as a protest against heavy-handed government attempts to compel them to assimilate into Canadian society, and as a rejection of the public education system. ${ }^{60}$ The arsons and violence of the 1960 s still resonated a decade later, and isolated incidents of arson continued in the early 1970s. School board offcials worried that the Freedomites would be emboldened if they allowed these parents to educate their children. The free school and Doukhobor parents were exchanging ideas about education, which must have increased trustees' worries. Initially, the school board threatened to arrest the parents who had withdrawn their children from the home school, but soon conceded that that the new residents, many of whom were not certified teachers, but had doctoral or masters degrees, had sufficient education to teach their children. Officials argued, however, that most people in the valley were not qualified to provide a useful education for their children. Echoing the priorities of the provincial curriculum, one board member stated "Sure, they can teach their children something about farming, or logging, or working in the bush. But what happens to the child who wants an education, who doesn't see his goal in life as a job in the bush cutting down trees or working in the sawmill." ${ }^{61}$ A good education would prepare children to leave rural areas.

Back-to-the-landers hoped to rejuvenate rural communities, and believed that rural skills were not anachronistic but were essential to self-reliance. Many of the homeschooling parents were also members of RARTS and therefore recognized the value of knowledge based in the regional economy and politics. They did not, as the Friends School did, integrate these practical skills for daily living with the provincial education. Parents rejected structured learning and encouraged students to pursue what interested them. Tom Drake explained, "Everything is curricular, even chopping wood, if that is what the student wants to learn." ${ }^{62}$ Teachers taught traditional academic subjects like writing, arithmetic, and science. Canadian history included an emphasis on Doukhobor history, prioritizing local knowledge and history over provincial curriculum objectives. The courses that were offered were based on the expertise of parents and community members who had time to share their skills with the children, such as judo, ballet, music, drama, candle-making, ecology, forestry management, and first aid. ${ }^{63}$ Students were not placed in grades and were free to attend the class, or to pursue self-guided reading and studying if they preferred.

The school moved between the houses of homeschooling parents, and children went to the workshops and farms of neighbours. Initially the lack of a permanent 
facility seemed to be complementary to the school's philosophy of education. The collective explained, "So the community school literally takes place in the community. This has been a major factor in drawing the community together . . . a unique mixture of personal and public life between grownups and kids which has been so amazing to experience." ${ }^{64}$ When enrollment increased to forty students, it became too large to be held in the small houses, and RARTS began to seek funding to complete the community centre, which could also be a permanent home for the school. Due to the controversies about government funding and the termination of federal programs designed for unemployed youth, RARTS did not get another grant for the community centre. Following the tradition of homesteading work bees, fundraisers, donations, and volunteer work built the community centre. Responding to criticism from detractors, the collective named the centre the Vallican Whole, and the free school became the Vallican Whole School.

Adults and children learned alongside each other during the four years of building the community centre, which they completed in 1976. A master carpenter provided some guidance, and people brought the skills that they had learned building their own homes and barns. Children were always at the site and many of them worked on the building. A report in the Fed-Up Newsletter, a food coop based in Vancouver that served the province, described children's participation: "The youngest carpenter able to do self-directed labour was nine years old. One aspect of the construction was coordinated by a sixteen year old. All of these people gained familiarity with their tools and developed their skills by helping with building projects on their family farms, or on the job itself." ${ }^{65}$ Marcia Braundy, educated at Antioch West, one of the organizers of the construction, and co-founder with Joel Harris of the Whole School, recalled that younger children helped to hammer down the floor; this gave them a sense of ownership of the building and a feeling of belonging in the community. Influenced by the consciousness-raising meetings that were beginning at the same time in the Slocan Valley, the collective organized a women's workday so that they could develop confidence in their construction skills, and half of the construction crew was female. Feminist values guided the school. Sam Simpson, a parent and coordinator, wrote a feminist set of principles that directed daily activities in the school, and Marcia Braundy taught women's studies courses to teenaged girls at the school.

In its new location, the administration of the school became more structured. The school hired teachers, but parents still taught courses in their area of expertise. A parent-teacher coop, coordinated by one of the parents, governed the school. Parents debated which courses would be offered and what resources the school would use, and disagreements mirrored the changing political convictions of people who moved to the community. The school remained committed to self-directed learning, and ultimately students could decide which courses they wanted to take. ${ }^{66}$ In 2008 , the Vallican Whole School moved from the community centre to its own building in Winlaw, another community in the valley. New parents who were not part of the 1970s counterculture administer the school, but it maintains its commitment to experience-based learning, and continues to offer courses, such as wilderness training, that are specific to its rural setting. ${ }^{.7}$ 


\section{Conclusion}

These were small school in remote parts of British Columbia, but their histories merit analysis because they demonstrate the diversity of rural transformations in late twentieth-century Canada, and the need to understand these changes alongside urban developments. Through a careful analysis of census data, Ruth Sandwell has recently challenged the narrative of urbanization in Canada, and argues that "the parallel history of Canada's growth and development as a vibrant rural country" deserves more attention. ${ }^{68}$ Rural communities continued to grow until 1971, and it was not until 1976 that rural populations began to decrease. Historians are beginning to examine how the back-to-the-land movement shaped these economic, political, and cultural transformations, and the emerging literature demonstrates that local contextualization is a fundamental to understanding changes and continuities. Yet these local stories are intrinsically connected to transnational migrations of people and ideas. People brought radical ideas about family, childrearing, and education to the Kootenays that corresponded to some traditions in the community and clashed with the conservative groups in the region. While they were aware of how they were different from their neighbours, those who became engaged in politics knew that it was important to engage in the place where they lived. They insisted that solutions to social problems had to be grounded in the realities of rural life, and more specifically in the material and cultural experiences of the West Kootenays. Alternative education was one way to assert local control over governance and the future of the region.

The Argenta Friends School and the Vallican Whole School introduced an alternative to the public school system in southeastern British Columbia that challenged hierarchical pedagogical methods. Radical educational theories that argued that students learned best when they were free to explore their own interests influenced parents and teachers. These ideas mirrored countercultural values of freedom and selfeducation, but they were also rooted in a respect for traditional knowledge sources. In Argenta, the Quaker values of simple lifestyles, critical engagement with social justices issues, and consensus shaped the administration and curriculum. These values were part of a longer tradition of Quaker opposition to inequality and authority. The counterculture in the Slocan Valley was more vocal about is rejection of mainstream values than the Argenta community. Believing that the public education system was stifling their children's development, these parents created an alternative school that did not discipline children and allowed them to explore their own interests. The school included courses that made children aware of the place where they lived, and taught them skills that would enable them to work in a rural areal. Whether the children who attended the Vallican Whole believed these were worthwhile lessons will be explored through oral histories with them.

These schools provided distinct community-based approaches for alternative education that incorporated rural skills. The Friends School gave students a voice, but expected them to complete the curriculum. Whole School teachers did not believe that students should meet provincially established standards and expectations. They shared a commitment to building intentional communities committed to social 
justice, peace, and ecology. These alternative schools attempted to instill a respect for rural lifestyles into their children that they could not receive in a public education system that focused on modern technological advancement. Including rural skills into the curriculum also recognized that children living in rural communities needed an education rooted in the place where they lived. Rejecting the centrally controlled public education system was a response to resistance from some people in the community, but it was more significantly an alternative to curriculum that corresponded to economic priorities established in the far-away provincial legislature.

\section{Notes}

1 Neil Sutherland, Growing Up: Childhood in English Canada from the Great War to the Age of Television (Toronto: University of Toronto Press, 1997); Mona Gleason, Normalizing the Ideal: Psychology, Schooling, and the Family in Postwar Canada (Toronto: University of Toronto Press, 1999); Dominique Marshall, The Social Origins of the Welfare State: Quebec Families, Compulsory Education, and Family Allowances, 19401955 (Waterloo: Wilfrid Laurier University Press, 2006).

2 Paul Axelrod, "Beyond the Progressive Education Debate: A Profile of Toronto Schooling in the 1950s," Historical Studies in Education 17, 2 (2005): 227-241; Mary Louise Adams, The Trouble with Normal: Postwar Youth and the Making of Heterosexuality (Toronto: University of Toronto Press, 1997); Christabelle Sethna, "Sex Education and the Cold War: Freezing Girls out of Sexual Education," Canadian Woman Studies/Les cahiers de la femme 17, 4 (1998): 57-61; Sutherland, Growing Up.

3 Ian McKay, Rebels, Reds, and Radicals: Rethinking Canada's Left History (Toronto: Between the Lines, 2005).

4 For consistency, I will generally use the Whole School, rather than the Free School, throughout this article. This also reflects the strong connection between the school and the Vallican Whole Community Centre during the period under discussion.

5 Bradford Rennie, The Rise of Agrarian Democracy: The United Farmers and Farm Women of Alberta, 1909-1921 (Toronto: University of Toronto Press, 2000); David Jones, "We Cannot Let it be Run by those who Do Not Understand Education: Agricultural Schooling in the Twenties," BC Studies 9, 1 (1978): 30-60; James Murton, Creating a Modern Countryside: Liberalism and Land Resettlement in British Columbia (Vancouver: UBC Press, 2007), chapter 2.

6 For a good overview, see Harley Steven Rothstein, "Alternative Schools in British Columbia, 1960-1975" (PhD, Vancouver: University of British Columbia, 1999).

7 Erwin Johanningmeier, "America at Risk and Sputnik: Compared and Reconsidered," American Educational Journal 37, no. 2 (2010): 347-365.

8 John Holt, How Children Fail (New York: Delacorte Press, 1964).

9 Jonathan Kozol, Death at an Early Age: The Destruction of the Hearts and Minds of Negro Children in the Boston Public Schools (Boston: Houghton Mifflin Company, 1967); Jonathan Kozol, Free Schools, First Revised. (New York: Bantam, 1972).

10 Kozol, Free Schools, 12.

11 Douglas Myers, "Where Have All the Free Schools Gone? A Conversation with Bob Davis, Satu Repo and George Martell,” This Magazine is about Schools, Winter 1972.

12 For a discussion of Rochdale College, see Stuart Henderson, "Off of the Streets and into the Fortress: Experiments in Hip Separatism at Toronto's Rochdale College," Canadian Historical Review 92, no. 1 (March 2011): 107-133. 
13 J. A. Young, "A Rural High School tries Freedom," This Magazine is About Schools, Winter 1967; "Find Ourselves \& Find Reality Hopefully . . . A Letter Home from Argenta Quaker School, BC," This Magazine is About Schools, 1967.

14 Robert M. Stamp, About Schools: What Every CanadianParent Should Know (Don Mills: New Press, 1975), 3-4. June Callwood and Michele Landsberg, prominent Canadian feminists, were hardly representative of staid suburban Canada. Valerie Korinek has explored the important connections between feminism and Chatelaine. Valerie Korinek, Roughing it in the Suburbs: Reading Chatelaine Magazine in the Fifties and Sixties (Toronto: University of Toronto Press, 2000).

15 Rothstein, "Alternative Schools in British Columbia, 1960-1975," 14.

16 The Royal Commission on Education, 1960.

17 By invoking the "ethos of the decade" it is not my intention to give credence to a culturally produced, nostalgic depiction of the 1960s. Indeed, I am convinced by arguments that call for more analysis of the continued importance of conservative politics during the decade. See for example, Gerard De Groot, The Sixties Unplugged: Kaleidoscopic History of a Disorderly Decade (Cambridge Mass.: Harvard University Press, 2008). While paying attention to continuities, it is important to understand what changed. See Joan Sangster, "Radical Ruptures: Feminism, Labour and the Left in the Long Sixties in Canada," American Review of Canadian Studies 40, 1 (Spring 2010): $1-21$.

18 Kozol, Free Schools; Stamp, About Schools: What Every Canadian Parent Should Know.

19 Rothstein, "Alternative Schools in British Columbia, 1960-1975," 11.

20 "Rural Education," The Smallholder 41 (March 1978), 696.

21 C. A. Bayly et al., "AHR Conversation: On Transnational History," American Historical Review 111, no. 5 (December 2006): 1441-1464.

22 Myrna Kostash, Long Way from Home: The Story of the Sixties Generation in Canada (Toronto: James Lorimer \& Company Publishers, 1980), 118.

23 Sharon Weaver, "Coming from Away: The Back-to-the-Land Movement in Cape Breton in the 1970s" (MA, Fredericton: University of New Brunswick, 2004).

24 Katherine Gordon, The Slocan: Portrait of a Valley (Winlaw, BC: Sononis Press, 2004).

25 Patricia Bambrick. Interview by author, 1 November 2010. Bambrick lived in an intentional community in Pass Creek, near Castlegar.

26 Jean Barman, The West Beyond the West: A History of British Columbia, Revised. (Toronto: University of Toronto Press, 1996), 145, 307-7; John McLaren, "The State, Child-Snatching, and the Law: The Seizure, Indoctrination of the Sons of Freedom Children in British Columbia, 1950-1960," in Regulating Lives: Historical Essays on the State, Society, the Individual, and the Law, ed. John McLaren, Robert Menzies, and Dorothy Chunn (Vancouver: UBC Press, 2002), 259-293.

27 Bonnie Baker, Nelson, BC, 26 October, 2010; Bob Inwood, Winlaw, BC, 23 October 2010; Marcia Braundy, Vallican, BC, 28 October 2010; Bob Ploss, Vancouver, BC, 18 July 2011. Sharon Weaver found similar patterns in communities where young people did not flaunt social conventions and respected the values of the established communities. Weaver, "Coming from Away"; Sharon Weaver, "First Encounters: 1970s Back-to-the-land, Cape Breton, NS and Denman, Hornby and Lasqueti Islands, BC," Oral History Forum d'histoire orale 30 (2010): 1-30. It is important to note that in the Kootenays, relationships with the established community varied. Public nudity and drug use, which was not practiced by all of the newcomers, offended some people and created tensions in the community.

28 Interview with Bob Ploss.

29 See Peter Schramm's interviews with Argenta elders. Interviews of Argenta Quakers and Long Tme Residents of Argenta, B. C. Canada. Videorecording, Peter Schramm, 2008. The Smallholder, a guide to rural living published by the Argenta Press since 1974, also published many letters and articles by Argenta residents who had travelled overseas. 
30 “About Argenta," The Smallholder, 69 (Summer 1990), 1584.

31 E. F. Schumacher, Small is Beautiful: Economics as if People Mattered (New York: Harper and Row, 1973); Andrew Kirk, "Appropriating Technology: The Whole Earth Catalog and Counterculture Environmental Politics," Environmental History 6, no. 3 (July 2001): 374-394; Andrew G. Kirk, Counterculture Green: The Whole Earth Catalog and American Environmentalism (Lawrence: University of Kansas Press, 2007); Sam Binkley, "The Seers of Menlo Park: The Discourse of Heroic Consumption in the 'Whole Earth Catalog," Journal of Consumer Culture 3, no. 3 (2003): 283-313; Fred Turner, From Counterculture to Cyberculture: Stewart Brand, the Whole Earth Network, and the Rise of Digital Utopianism (Chicago: University of Chicago Press, 2006); Alan MacEachern, The Institute of Man and Resources: An Environmental Fable (Charlottetown: Island Studies Press, 2003).

32 A local example of this literature is Christian Bruyère, Country Comforts: The New Homesteader's Handbook (New York: Drake Publishers, 1976). Illustrated by Rob Inwood, the handbook was produced by Slocan Valley back-to-the-landers, but is not specific to the area. The Smallholder Magazine used the subtitle "an exchange of ideas and information of interest to country people." It published letters with advice and questions by organic and small-scale farmers who lived in the Pacific Northwest.

33 Letters to The Smallholder Magazine indicate that parents in other communities were also eager to establish free schools that would provide an education that would be useful in the country. People wrote letters asking which intentional communities had schools, and advertised for teachers who had skills to each in alternative, wilderness-based schools. "Where Are all our Free Schools" and "Buy Sell \& Swap Ad for Teacher," The Smallholder 31 (March 1977), 463, 476.

34 "About Argenta," The Smallholder 71 (Summer 1991), 1651. This article is a reprint of an undated article in the Friends of Peace Pilgrim newsletter by Ann Rush, an early Argenta resident who had left the community.

35 When back-to-the-landers arrived in the late 1960s, some of the parents organized an alternative elementary school. The teachers had education degrees, but not all of them were qualified to teach in British Columbia. Interviews of Argenta Quakers, V. 4 Don and Liz Tanner, 19 July 2008, Nelson, BC.

36 Rothstein, "Alternative Schools in British Columbia, 1960-1975," 86.

37 Students and Staff of Argenta Friends School, The Argenta Cookbook (Argenta, BC: Argenta Friends Press, 1979).

38 Interviews of Argenta Quakers, V. 4 Don and Liz Tanner.

39 "Argenta Friends Press," The Smallholder, Summer 1991; Students and Staff of Argenta Friends School, The Argenta Cookbook (Argenta, BC: Argenta Friends Press, 1979). The Argenta Press has published The Smallholder since 1978.

40 Rothstein, "Alternative Schools in British Columbia, 1960-1975," 125.

41 Interviews of Argenta Quakers, V. 4, Anni Valentine, 24 June 2008.

42 Interviews of Argenta Quakers, V. 2 Betty Tillotson, June 16, 2008, Argenta BC.

43 "Buy and Swap" (Advertisment for teacher), The Smallholder 48 (June 1981), 948.

44 Interviews with Argenta Quakers, V. 6, Betty Polster, 19 July 2008, Duncan, BC.

45 Peter Schramm, interview by author, 24 October, Nelson, BC.

46 Ric Valentine, interview by author, 26 October 2010, Argenta, BC.

47 Ibid.

48 Michael Pratt, interview by author, 21 October 2010, Nelson, BC.

49 Paul Carbray, "Free School Tinder to Bad Situation?," Nelson Daily News, August 7, 1973. In interviews, people told me that their children were not happy in the public school system. Sam Simpson was the mother of a mixed race child who faced racism in the school. Sam Simpson, interview by author, 19 May 2000, Winlaw BC. See also Corky Evans, interview by author, 9 October 2010; Interviews with Michael Pratt and Marcia Braundy. There was no consensus within the community about organizing an 
autonomous school. Bob Ploss decided not to get involved with the Whole School because he and his wife thought that it was important for their children to integrate into the community. His son later told him that the back-to-the-land kids did not fit in; the kids who ate sandwiches made from whole wheat bread and those who ate white bread sat at opposite sides of the lunchroom. Bob Ploss, interview with author.

50 Moira Farrow, "Free School Starts Out in a Bind: Slocan Valley Organizer Says Worst is Over," Vancouver Sun, November 9, 1973.

51 "Slocan Parents Protest Increased School Costs," Nelson Daily News, November 1, 1972; "Questionnaire Upcoming: New School Facilities in Valley?," Nelson Daily News, February 19, 1975.

52 Moe Lyons, "From a '70s 'Free School' to an '80s Alternative-An Early History and a Few Moments in the Life of the Whole School," Images, Fall 1987, 8.

53 "Letter to Editor," Nelson Daily News, June 16, 1973; "Opportunities for Youth Program Comes Under Fire at Slocan Meeting," Nelson Daily News, January 4, 1972.

54 "Long Range Purpose of the Rural Alternatives Research \& Training Center," April 1971, RARTS Records, Vallican, BC.

55 Unemployment was high in part by choice. Some newcomers worked temporarily when they had used their savings. Those who wanted to work in the mills were sometimes refused employment because of their "hippie" appearance. "KAK Red Neck?" The Arrow, June 1973.

56 “OFY Application,” 1971, RARTS Records.

57 "Building In-Service Training Project, Final Report," September 1971, RARTS records.

58 "Controversial Vallican Project: Hippies, Nudies and Hole in the Ground," Nelson Daily News, n. d.

59 "Letter to Editor."

60 McLaren, "The State, Child-Snatching, and the Law."

61 Paul Carbray, "Free School Tinder to Bad Situation?," Nelson Daily News, August 7, 1973.

62 Peggy Pawelko, "Life at the Free School: Diversified but Never Boring," The Trail Times, June 2, 1973.

63 Thirty-five Resource People Taught Courses. The All Night Collective, "Vallican: The (W)Hole Story," The Arrow, March 1974, 8.

64 Ibid.

65 "How We Did It - What We Learned," Fed Up Newsletter (August 1975). There are photographs of children working in the photographic exhibit about the construction of the Vallican Whole. Building the Building - Building Community, Kootenay Gallery, Castlegar, BC, 29 July - 10 September 2011.

66 Lyons, "From a '70s 'Free School' to an '80s Alternative-An Early History and a Few Moments in the life of the Whole School."

67 http://vallicanwholeschool.com/

68 Ruth W. Sandwell, "Notes Toward a History of Rural Canada, 1870-1940," Social Transformation in Rural Canada, forthcoming. 